\title{
The renewed currency of Raúl Prebisch
}

\author{
Rubens Ricupero
}

$\mathrm{T}$

his article begins with a brief evocation of the main features of the legacy left to us by Raúl Prebisch, not only from the strictly intellectual point of view, but also as a model of humanism. It then goes on to deal with the present situation of the world, with special emphasis on trade, and highlights the return of a war economy mentality and the instability reigning in the oil market, both of which militate against the greater investment needed in order for the world economy to grow at a satisfactory rate. It notes that in spite of all this, in the present circumstances there has nevertheless been some recovery of growth and revitalization of trade. Finally, it analyses the structural changes which have taken place or are under way in the world trade system and, in particular, the extent to which those changes resemble those that Prebisch hoped for or fall short of his expectations. 


\title{
Introduction
}

In this article I should like first of all to recall what, in my opinion, are the main features of the legacy left to us by Raúl Prebisch, not only from the strictly intellectual point of view, but also as a model of humanism. Secondly, I should like to refer to what we might call the "here and now" - the present situation, what is going on in the world of today- with special emphasis on trade, which is my main area of experience. Due to the circumstances of my diplomatic life, my long-standing link with trade has been perhaps my most outstanding characteristic, unlike my four predecessors in UNCTAD. They did not have direct experience with the General Agreement on Tariffs and Trade (GATT), as I did in my posts as chairman of the
GATT Council and the GATT Contracting Parties and as a negotiator, and this experience has perhaps helped me to develop a different outlook which can only be gained through experience in the realities of negotiating trade agreements.

Thirdly, I will review the structural changes which have taken place or are under way in the world trade system, and especially the extent to which those changes resemble those that Prebisch hoped for, or else fall short of his expectations. Finally, by way of a brief conclusion, I will say a few words about the present situation of Latin America, which is where I come from and where I hope to be living again very soon and to keep on collaborating with ECLAC from closer at hand.

\section{II}

\section{Prebisch's intellectual and humanistic legacy}

\author{
"...when we contemplate the times we are living in today it is hard \\ to be optimistic. I believe, however, that we must keep up our struggle, \\ which does not only concern the international context but also our own \\ countries. It is not just a question of a new international economic \\ order but of a new economic, social and ethical order at the national \\ level too. These are the great problems that we must solve in Latin \\ America, though they will entail harsh sacrifices" (Prebisch, 1983).
}

These were Raúl Prebisch's closing words, on 6 July 1982, at the end of the series of lectures organized by UNCTAD in his honour in Geneva. They highlight what I consider to be the most important aspect of all that he has bequeathed to us: his ethical and moral commitment to promoting the social interests of Latin Americans.

I used another quotation from the same lecture at the beginning of my address at the seminar organized by ECLAC in Santiago, Chile, to commemorate the centenary of Prebisch's birth. I entitled that address "The Globalization of Raúl Prebisch", explaining that

This article reproduces the text of a master class delivered by the author at the Economic Commission for Latin America and the Caribbean (ECLAC) in Santiago, Chile, on 27 August 2004 as part of the Fourth Raúl Prebisch Memorial Lecture Series.
I was using the term globalization in a dual sense: "first, to describe Prebisch's personal and intellectual progression towards an increasingly universal dimension: from his native Argentina to Latin America, and from there to the world economic system as a whole, in UnCTAD. Second, to suggest that one of the best ways of remembering this great Latin American is to try to imagine what globalization would be like had it followed his design and intentions, rather than turning out as it has, generating and provoking a growing movement of massive rejection ..." (Ricupero, 2001).

What I want to refer to now is not the process of evolution which led Prebisch's thinking to extend to increasingly broad areas, to the point where it covered the whole of the world economic system, but to the 
way that thinking remained valid over time, and the constant updating it has undergone: what we might call its renewed currency. This is not to say that he never made a mistake, that his ideas were timeless, or that we should forget what he himself said in his contribution to Pioneers in Development: that "my thinking on development has gone through successive stages under the influence of changing conditions and the broadening of my own experience" (Prebisch, 1984).

Far from allowing himself to be immobilized by immutable ideologies or ideas, "What is noteworthy" says Jagdish N. Bhagwati, "is the way he has been able to interact with his economic and political environment and thus grow as an economist" (Bhagwati, 1984).

The ongoing currency of an idea is not measured by drawing up a balance-sheet of hits and misses, but rather by the ongoing relevance of the topics and concerns it deals with, and perhaps more by the questions it raises than the answers it gives. Thus, all the main themes of Prebisch's future work and of the debate in progress today were already present in The Economic Development of Latin America and its principal problems (Prebisch, 1949): the centreperiphery dualism; his "splendid terminology", as Bhagwati called it; and the vital importance of technical progress, the link between foreign trade and development, foreign investment, import substitution, interdependence, and commodity prices.

Another basic factor in the influence of Prebisch's example was also clearly visible in that now-distant study: the emphasis he places on making the actual prevailing conditions the starting point for creating a vision adapted to the circumstances of space and time. As he wrote at that time: "The reflective knowledge of external matters must not be confused with mental subjection to alien ideas, from which we are only very slowly learning to free ourselves" (Prebisch, 1949). Thirty-three years later, in Prebisch's lecture at UNCTAD in 1982, he was to return to this approach: "In those years of the Great Depression, a phenomenon of intellectual emancipation began in Latin America which involved looking at the theories of the "centre" with a critical eye. Not with an attitude of intellectual arrogance - for those theories nevertheless have great value - but with a realization that they need to be subjected to critical study. (...) it is this critical study which makes us strive to seek our own paths to development — paths that do not involve imitating anyone - and to try to understand those conditions and meet the economic, social and moral demands of development —in other words, paths based on equity" (Prebisch, 1983).

He never gave up his attitude of consistently trying to judge theories in terms of their practical results, making that a test of their viability. His references to what was going on in the world -in the countries of the "centre", in the United States, and most often of all, in Latin America- made him a thinker who was always open and willing to accept change, new developments and self-criticism. Living as he did in the same years when Ortega y Gasset coined his famous phrase "man is himself and his circumstances", he was an outstanding embodiment of the American condition as well as of his own personal and national situation.

In this sense, it is strange that in his essay on his "five stages" (Prebisch, 1984) he does not enlarge on his own experience of "globalization" (corresponding to the fourth stage: that of his period in UNCTAD), and this did not escape the attention of two of the commentators on that text (Albert Fishlow and Jagdish N. Bhagwati). This should not be seen, however, as a reflection of a stronger sense of frustration or failure regarding that stage in his intellectual career, since his last texts on Latin America at the time of the military dictatorships and the debt crisis in the "lost decade" of the 1980s were not exactly filled with hope either. The explanation, I believe, is simply that he had to return every time to the Latin American environment in order to nourish his understanding of the world on the basis of a reality which he knew so well. His Latin American roots were so deep that this became a habit, perhaps unconsciously, to such a point that in a text intended in principle for an international audience and dealing with the developing countries and the periphery as a whole, at the end he moved from the general (the international level) to the specific, saying "These are the great problems that we must solve in Latin America, though they will entail harsh sacrifices" (Prebisch, 1983), as though those problems were not the same on other continents.

In the same text, he expressed his regret that "when these great years of prosperity came and we allowed ourselves to be dazzled by the centres, this effort to seek our own ways was interrupted" (Prebisch, 1983). In a surprising preview of some present trends, he criticized the fact that "the mutual trade initiatives among the countries of the region were considerably weakened because we believed that a new era was dawning for the world in which exports of manufactures to the centres would solve the great problems of the external 
bottleneck ..... We let ourselves be seduced, as is perhaps only natural, by the consequences of the prosperity of the centres. The pendulum swung to the other extreme: no more import substitution, no more mutual trade efforts, our whole future lay in outwardoriented growth and in taking advantage of the markets of the centres" (Prebisch, 1983).

These words describe what is happening today even better than what was happening in 1982, which was to be marked, a few months after the UNCTAD meeting in July of that year, by the beginning of the long external debt crisis of the region, with the Mexican collapse in October and the ensuing lost decade or decade and a half. It would not be hard to find further examples of Prebisch's extraordinarily perceptive and almost prophetic foresight and his capacity to predict many phenomena which are now of more obviously decisive importance than they were when he described them.

Instead of making an exhaustive list, however, I will now highlight two fundamental and permanent aspects of Prebisch's intellectual legacy. The first is what might be called his attitude towards the world: his search for a truly Latin American path, based on our own actual situation, as one of his main criteria for critically appraising and adapting imported theories and therapies.

The second is what lies at the root of the criticisms he levelled against the excesses committed in the Latin American governments' radical change of course in the 1980s, which he sums up as follows: “.... looking around us, we have turned our backs on a policy which, in my opinion, with all its undoubted defects and faults, we should have continued to follow, taking advantage of our accumulated experience in order to perfect it" (Prebisch, 1983). The reason for his rejection of what he called "conventional theories" was that they took no account of the social structure and its continual changes. Apart from the shortcomings he identified in the explanatory capacity of conventional theories, even with respect to the economic system of the centres, what seemed most serious to him was that, when applied to Latin America, those formulas would make it necessary to leave out "the great mass of the population which industrialization had reached only to a very incipient extent" (Prebisch, 1983).

The process of marginalization begins with the frantic imitation of the centres' advanced forms of consumption by the elite social groups of the Latin American periphery. Thanks to the enormous disparities in income distribution, those groups were able to rapidly assimilate the centres' forms of consumption. This occurred "to the detriment of the accumulation of reproductive capital, which is the only thing that can solve our problems of social exclusion: that is to say, the fact that great masses of the population are relegated to the bottom of the system, with low incomes, very low productivity, and a large number of unemployed, because not enough reproductive capital has been accumulated to increase the employment and productivity of the masses" (Prebisch, 1983).

That description of the Latin American situation was penned exactly 22 years ago: the space of a generation. We would all like to be able to say that it is no more than that: something from the past, now overtaken by progress, that ultimately belongs to a time which is now on the way to oblivion. Can we still maintain such a position, however, when we read the Preliminary Overview of the Economies of Latin America and the Caribbean 2003 (ECLAC, 2003), published in December of last year? This overview contains the following words, which deplore the fact that, in spite of the growth registered in 2003, the region's per capita GDP remained flat, at a level $1.5 \%$ below that of 1997: "The six years of negative per capita growth caused social damage that will take time to reverse. There are 20 million more poor Latin Americans in 2003 than there were in 1997. Unemployment has increased by two percentage points during this period and is now at 10.7\%" (ECLAC, 2003). Elsewhere, the same publication informs us that in that same year, $44 \%$ of the region's population was living in poverty.

I am well aware, of course, that these disturbing figures are the result of a particularly adverse set of factors including, among others, the financial collapse in Argentina in 2001 and the economic and social consequences of the political problems in Venezuela and other countries. I am also well aware that they represent a region-wide average and that there are comforting exceptions in which countries have significantly reduced poverty and increased growth thanks to sound macroeconomic policies, as in the case of Chile, which all of us admire. It is likely, too, that the more promising growth prospects in 2004 and, I hope, the coming years in general will soon bring positive results in terms of reducing unemployment.

Nevertheless, there are undeniable realities which cannot be ignored and which make it possible to argue that Prebisch's views continue to be valid today.

Thus, armed with this legacy which permits us to take a clear-cut stand, with a moral commitment to socially equitable development and with a critical 
intellectual attitude devoid of ideological prejudices and based on our real situation, we will now close this section and go on to the next one, inspired by another exhortation of Prebisch, which formed the title of the lecture he gave in Medellín shortly before his death: "It is imperative to renew our ideas".

\section{III}

\section{The here and now}

This article is based on the Prebisch lecture I delivered at ECLAC on 27 August 2004, three years after the events held at ECLAC to commemorate the centenary of Prebisch's birth. On that first occasion, I spoke on 28 August 2001, exactly 15 days before the terrorist attacks that changed the world on 11 September of that year.

Of course I had then no idea of what was going to happen in the world or the changes that would take place from that moment. I will not try to make an exhaustive list of those changes, but will merely refer to a few of them which have had an influence on the world economic and trade situation, which is my main subject.

I should like to note first of all that what has really changed is that we have once again come to live in a war economy. In some respects, it sometimes seems that we have gone back to the 1970s, when the war economy due to the Vietnam conflict combined with other factors which are not present today, such as inflation.

At the present time, we have at least two conditions which are similar to those prevailing at that time: a war economy, once again combined with great instability in the oil markets. When I speak of a war economy, what I mean is that we have now left behind us the mental atmosphere in which the prevailing idea was that what mattered was economic globalization. Between the fall of the Berlin Wall and the terrorist attacks of 11 September, the factors which were considered important were the market, globalization, and the facilitation of all kinds of transactions. We have now passed from that mental attitude to another which is dominated by the concern for security. The United States claims that it is engaged in a war on terrorism, and we have no idea when that war will end. In less than three years we have had a war in Afghanistan and another in Iraq, and we are already reading in the newspapers that there are plans, not to go to war, but to destabilize countries such as Iran. These are serious plans announced in such respected papers as the London Times.

This is a period of almost constant mobilization, in which one conflict leads not to peace but to a new conflict, with ever-increasing use of human, military and financial resources. How will all this end? I have no idea, and I do not wish to make any predictions. I am simply noting the fact that there is a war economy, whose first consequence is the excessive strengthening of the State and its powers. The State is being strengthened vis-à-vis the market and civil society, and it is being strengthened because military, strategic, security and political considerations have become a question of life or death. As Napoleon said, "the intendancy goes on": the economy, trade, finance, etc. must all go on.

The State lays out resources to strengthen its security. This is why, in the United States electoral campaign, concern over the fiscal deficit is less important than strategic concerns. This is why extraordinary increases in budget allocations are approved in order to create new capabilities in respect of external or internal security. It thus represents a farreaching change. I do not know how long it will last, but in my opinion, it is incompatible in the long term with the original idea of globalization.

What was the idée-force of globalization? It was the belief that while frontiers would continue to exist, they would become irrelevant because transactions, which would be increasingly easy, would not be carried out from one side of a border to the other (cross-border transactions) but would leapfrog them (trans-border transactions), like the electronic transactions effected over the Internet, which are not registered by any kind of customs authority. That was the conviction underlying globalization: that goods would transcend frontiers, as would companies (but not workers, for this was never added), loans and investments.

If the excessive concern with security lasts too long, it will not put an end to globalization, but it will 
raise more obstacles to it. Anyone who has visited the United States recently knows what I am talking about, so not many more examples are needed. There has been a radical and important change: a return to the spirit of a war economy. What happened in an area of high strategic value for oil production obviously has an impact on the price of that product. Among the many reasons (explicit or implicit) given in order to explain the war in Iraq - the existence of weapons of mass destruction, possible links with terrorist movementsthere was always the idea that a pacified, democratic Iraq would be one more guarantee of a steady supply of oil. This reason too has proved to be false, however, because now the frequent interruptions in Iraq's oil production are one of the factors behind the volatility of oil prices, together with the increased demand of countries such as China, the problems in Russia over the Yukos company, the political problems in Venezuela, and especially the worst nightmare of all: the growing instability of Saudi Arabia.

Saudi Arabia alone produces over $10 \%$ of the world's oil. In 1979, when the revolution of the ayatollahs caused the withdrawal of Iranian oil from the market, even though the volume of Iran's oil production is not comparable with that of Saudi Arabia the price per barrel soared to a level which would be equivalent to US $\$ 100$ today. What would happen if something similar took place in Saudi Arabia? I am singling out these two factors, the war economy and oil, for a very simple reason: they both affect the sense of security of those who have to take investment decisions.

The world economy will only grow at a satisfactory rate if the level of investment is increasingly high. In a situation like that of the present, where the main concern is insecurity and the unpredictability of a war economy and of oil prices, no major new investment trends are to be expected. I believe this is an extremely important factor in the present situation, although there are many others to which I will not refer here. Even so, we have been fortunate in that, after the brief recession in 2001, which followed, among other things, the big rise in oil prices in 2000, the world economy nevertheless began to recover to the point where there are already growth estimates of around $4 \%$ for this year. This is largely due to the growth of China and India and the recovery of the United States economy, although the latter is already beginning to raise doubts because of the less promising results of the second half of 2004 and the enormous increase, by over US $\$ 9$ billion, in the trade deficit of that country in June.
This climate of growth has brought with it a revival of world trade, which, after an exceptional year in 2000 , with growth of over $13 \%$, followed by a contraction of $-1 \%$ in 2001 and some signs of recovery in 2002, turned in a growth rate of $4.5 \%$ in 2003 . The excellent Preliminary Overview of the Economies of Latin American and the Caribbean 2003, published by ECLAC in December of that year, showed how this growth has enabled Latin America to post several new records for export growth, a trade surplus of US\$ 41 billion, and a current account surplus of US\$ 6 billion. The publication in question indicates that nearly all the countries, with a few notable exceptions, turned in a good performance. We have already seen the first fruits of this recovery in trade, and the tendency has been further accentuated this year. The most conservative estimates — such as those of the World Trade Organization (WTO) — indicate that trade could grow by 7\% in 2004. The most recent data of the Organisation for Economic Co-operation and Development (OECD) point to growth rates of $8.6 \%$ this year and possibly $10.2 \%$ next year, provided the factors affecting world growth, such as oil, do not cause too many problems.

It is true that, at least in many continents and regions, this growth is explained largely by changes in exchange rates and the prices of goods and services. This is not so in Latin America, and still less in Asia, but in Western Europe much of the growth is due rather to factors connected with exchange rates and prices. Nevertheless, it must be acknowledged that 2004 has been an exceptional year in terms of trade, and the future prospects are good too, as shown by the figures for next year announced by OECD.

We find ourselves up against a paradox, however: how is it that in a year in which almost everything is going so well, only the trade negotiations are going badly? Normally, when the world economy is growing and there is a recovery in most commodity prices, the natural situation is for such negotiations to make progress. We have recently observed, however, that on the contrary there were problems in the Cancún negotiations last year and in the Geneva negotiations this year, which made no progress right up to the last moment, raising fears that no agreement would be reached. The negotiations on the Free Trade Area of the Americas (FTAA) have practically ceased to exist, at least in the form in which they were originally proposed, and FTAA is no longer the same scheme that was originally proposed 10 years ago. The negotiations between MERCOSUR and the European Union have likewise made little headway. Some free trade 
agreements have been signed, such as the one between Chile and the United States, but none of them could be called a landmark in terms of important issues. The agreement between Australia and the United States, for example, has had practically no immediate positive impact in thorny areas such as agriculture.

What is the explanation for this apparent contradiction? In my opinion, the explanation is very simple: the problems are political rather than economic or trade-related. Thus, the trade negotiations in GATT, which concentrated for many years on tariffs for industrial goods, have practically run out of steam, because the easy issues have already been dealt with, and what is left is much more difficult. The hard-core issues concerning protectionism - what was called at Geneva the unfinished business of the Tokyo and Uruguay Rounds (i.e., the unfinished business of all the rounds)_ remain to be solved.

GATT was able to make rapid progress in the 1950s, 1960s and 1970s because it left out the most difficult issues: agriculture, textiles, clothing, and footwear and leather products. All these products were isolated and made subject to special rules.

Progress has been made in the sectors where all the parties have wanted to make headway, but sooner or later it will be necessary to deal with the most fundamental problems. These issues were left aside for a very good reason, because they are extremely complex, and now that the day has come to tackle them, all those concerned are beginning to realize that the challenge is very great indeed; not something that is going to disappear after the United States elections. With regard to agriculture, for example, I am quite sure that the difficulties will be very great and will last for many years. This is due not only to the reluctance of Europe and the United States, but also of big developing countries such as China, India, etc.

This problem of the current situation had an encouraging result a few weeks ago: a framework agreement which merely served to stop the negotiations from coming to a halt altogether. In reality, if one analyses the real content of this agreement, it must be acknowledged that it is extremely minimalist. Its main advantage is that it avoided the worst: i.e., it prevented the Doha Round from dying in its tracks. That Round was due to end in late 2004. If it had not even been possible to agree to keep on negotiating, it would have starved to death for want of encouragement. The agreement which has been reached, which is built on a number of creative ambiguities, makes it possible for the negotiations to be resumed next year. This type of ambiguity exists in the agricultural sector, in the socalled three pillars of agriculture. With regard to export subsidies, the idea is accepted that some day, in an uncertain and unknown future, they must be eliminated. But when? No-one knows, and the objective can only be attained if there is parallel progress regarding other forms of subsidies, credits, food aid, etc.

With regard to internal agricultural support measures, although it is true that agreement has been reached in principle on limits which must not be exceeded, it is also true that it has been agreed, at least in principle, to take quite a flexible view on the socalled "blue box", 1 thus opening up the possibility of allowing countries like the United States to legalize through the negotiations what they lost under the dispute settlement system. The agreement does not say in as many words that this will happen, but it does leave open that possibility.

With regard to access to markets for agricultural products, everything remains to be done. The agreement on industrial products is quite vague, and it does not lay down any rules for defining whether negotiation in some sectors where tariffs would be reduced to zero should be obligatory or voluntary. Some five, six or seven key questions remain to be settled in the negotiations, and it is impossible to predict the result.

In spite of all the foregoing, however, the agreement is undoubtedly a positive step forward and represents the most that could be achieved at that moment. It makes it possible to keep the multilateral system alive, since thanks to it the negotiations can be resumed with greater enthusiasm, once an unfavourable political situation has been left behind. I believe there is a reasonable possibility that these negotiations will finish, not in 2005 but, at least in terms of their fundamental aspects, at the end of 2006. The negotiating mandate giving the Executive the United States Trade Promotion Authority expires on 1 June 2005, but it contains an almost automatic renewal clause for two years, i.e., up to June 2007. In my opinion, the most likely outcome is that the negotiations will be successful and there will be steady progress. In other words, I would wager that the results will be moderately positive in the not too distant future.

\footnotetext{
1 The term "blue box" refers to internal aid measures to limit production which are specifically devoid of any reduction commitments, according to the bilateral agreement between the United States and the European Union.
} 


\section{IV}

\section{Structural changes in the international trade system}

I will now analyse what I consider to be the main structural changes, not in the areas of political issues or security, but specifically in the trade system. I will not try to deal with everything that Prebisch proposed, but will concentrate on some fundamental aspects of his thinking, in order to determine how and how far they have evolved in practice.

I shall refer first of all to the world trade system: what did Prebisch expect from the institutionalization of this system? Secondly, I will deal with the export of manufactures, and thirdly with the real reciprocity - not the merely legal or apparent reciprocitydisplayed with regard to the developing countries and the "special and differentiated treatment" under the Generalized System of Preferences. I will also deal with the question of services, although these were not part of Prebisch's concerns. Finally, I will make some remarks on a matter which he anticipated very well: interdependence.

I should like to make it clear that what I will be doing is simply to set forth the problems, because I do not really have many proposals to make for their solution. That is the challenge we will all have to face in the future. The first problem is that of the international or multilateral trade system. I will take as my starting point the great report that Prebisch presented to the first session of UNCTAD 40 years ago, in 1964. In that report, Prebisch said that GATT was far from attaining the universality it needed in order to be really effective and international. At that time, the members of GATT numbered a little over 60 . Furthermore, as he said, GATT was not a supranational organization capable of adopting rules that would prevail over national laws. In that respect, there has been rapid progress, since in 1995 the World Trade Organization (wTO) was set up at the meeting in Marrakesh, although it did not have the features that Prebisch had envisaged for an organization of that type. Nevertheless, the wTO is an organization which has some supranational features and comes close to universality, although it is not yet completely universal. China recently became a member, but countries such as Iran have not yet been admitted, and political reasons prevent the initiation of negotiations for this. Saudi Arabia and the Russian Federation are not members either, and various countries of the former Yugoslavia, as well as Vietnam, are still in the negotiating stage. Even so, the wTo currently has 149 members, which is pretty reasonable in terms of universality. In this sense, it can be said that the vision set forth in Prebisch's report has been turned into reality.

With regard to the second point, the export of manufactures, there is no point in repeating what everybody already knows. For Prebisch, the solution to the problems of developing countries such as those of Latin America is industrialization, combined with the possibility of exporting more and more manufactures to the centres. His constant struggle was aimed at opening up the markets of the centres so that the manufactures of countries on the periphery could have access to them, and he criticized the reluctance of the centres to open up their markets for the products of mature industries. This is an interesting case in which Prebisch's expectations have largely been fulfilled, but the results have not been all that he hoped for.

Today, over $70 \%$ of the exports of the developing countries as a whole are manufactures, albeit with differing degrees of technological content. The developing countries' share in global trade in manufactures is very high and is growing all the time.

This phenomenon has brought with it two main problems, however: first, there is a high degree of concentration of those exports, and second, the export of manufactures has not always brought the benefits that Prebisch expected from technological progress and the increase in productivity and value added.

The first of these problems is clearly visible in the case of China. Everyone knows that China currently tends to attract all the mature industries of the world. The North Americans, for example, have already transferred to China whole segments of their manufacturing sector which no longer enjoy protection in the United States. The products of those industries are no longer manufactured in the United States, but United States companies produce them in China with 
Chinese labour. The same occurs in the case of many other products in which China has advantages, especially in terms of labour costs, with the result that entire industries have migrated to China.

The case of Brazil is well known. In the 1970s, Brazil was the main exporter of footwear to the United States. Today, however, Brazil provides only $6 \%$ of United States imports of footwear, while China provides over $60 \%$. To some extent, the transfer of mature industries has also acted to the detriment of other developing countries. It is not only a question of the Mexican maquila industry, where it is well known the Mexico has lost 250,000 jobs in this sector in recent years. Other countries, such as Vietnam, are also following the same path. In other words, it may be said that the phenomenon of increased exports of manufactures has basically been concentrated in East Asia. Even among the other Asian countries, there is now a tendency to transfer those industries to China and Vietnam. Taiwan, for example, is holding on to research and design activities in the field of electronic goods but increasingly manufacturing its physical products in mainland China rather than on the island. This phenomenon has done nothing to benefit Latin America.

The second problem is that it is not enough to export manufactures with a high content of technology: what really matters is the value added in such exports. What is the increase in what might be called the index of value added in the manufacture of export products? What has happened is that many countries which export technologically sophisticated products do so basically on production lines in which they import the inputs, assemble them, and then re-export them. This is what occurs in the maquila firms, but it is not the only case in which the actual value added is relatively insignificant.

The contribution to the local economy made by this type of activity does exist, and it is positive in terms of employment, wages and other aspects, but it has nothing to do with Prebisch's dream of real technological progress that spreads to the whole of the economy. In a way, these activities tend to be enclaves within an economy and have few linkages with the other sectors.

What has happened in this respect in comparison with what was envisaged in the 1960s? In those days, economists did not have any clear idea of a phenomenon to which we are completely accustomed today: that production would cease to be of a national nature. Through the transnational corporations, production has come to be broken down into stages, which these firms allocate to their various subsidiaries for the production of particular goods or services in order to obtain economies of scale through specialization. What is strange is that this phenomenon has been ignored for so long, because in Latin America we were witnesses of the beginning of this tendency long before anyone talked about globalization. When I was a young man, I lived in Buenos Aires as the officer in charge of the Brazilian trade office. At that time, Brazil still exported to Argentina the same products as in the nineteenth century - pinewood, yerba mate, bananas and coffee- and this began to change thanks to an idea put forward by ECLAC and Prebisch: the Latin American Free Trade Association (LAFTA), which was formed as a result of the 1960 Treaty of Montevideo. That treaty opened up the possibility of negotiating what were called sectoral integration agreements. What happened, however, was that we Latin Americans did not have continental-level firms. Our firms were national, local, provincial and those who took full advantage of the treaty were companies like IBM, Olivetti or Burroughs, which made use of these agreements by dividing up their production lines and manufacturing some things in Mexico and others in Argentina or Brazil. This was the beginning of what would later become one of the two great motive forces of globalization. One was the revolution in telecommunications and information technology, while the other was the internationalization of production and distribution chains.

What Prebisch had in mind when he advocated the transfer of mature industries to Latin America was a national system of integrated production. He had not anticipated that this would take place as it did. It may be added that there is something we have always lacked and still do not have: an awareness of the need to promote services. We are now witnessing an extraordinary phenomenon in this respect in India, which is already exporting over US\$ 15 billion in services through external subcontracting, software and the operation of call centres.

Some Caribbean countries are also doing this, but in Latin America we are still not really prepared to take advantage of the great potential of services.

The developing countries talk a lot about manufacturing but very little about services, which is a sector in which all of them are very vulnerable. India, for example, is very concerned about this, because in this field there are no clear legal commitments designed to protect subcontracting. If tomorrow a country like 
the United States or France decides to take measures against external subcontracting, those measures will not be considered illegal, because among other things — and this is a really ironical situation - few of the developing countries have adhered to the Tokyo Round agreement on public sector purchases, which is where protectionist-minded politicians now want to impose limits.

Today, both ECLAC and UNCTAD are working harder in this respect and addressing problems to which we had perhaps failed to pay due attention: i.e., those on the supply side of the production system. Through the important work of Fernando Fajnzylber, ECLAC put forward the issue of changing production patterns with social equity. Even so, not much progress has been made in this field either in changing production patterns or in equity.

Undeniably, we are tending to go back to the past in terms of exports. There are some worthy exceptions, but in general we are returning to a situation of specialization in products based on natural resources. The case of Brazil is typical. Except for some examples such as the sale of aircraft by EMBRAER, Brazil's main export successes are in the field of agro-industry (basically agriculture and stock-raising).

Another issue of a more structural nature is that of trade blocs. This was not one of the subjects dealt with by Prebisch: quite to the contrary. He wanted to achieve the integration of Latin America and of the developing countries in general. Until recently, there was a great deal of talk about how the world was on the way towards splitting up into three great trade blocs: Europe, with the Euro as its currency; ourselves and the United States in the Western Hemisphere, with the dollar, and the Asians, with Japan and the yen. This has only occurred in part, however. The great bloc which has really arisen is that of the Asians with the United States. The real situation of the world trade system and the world system of payments is that the Asians are growing thanks to the United States market and are buying dollars and Treasury bonds so that the North Americans can continue to be not so much lenders of last resort as consumers of last resort.

We have reached a very curious situation of symbiosis. Someone said that today there are only two kinds of developing countries. In the first category are those that finance their development by exporting to the United States and building up reserves which prevent the depreciation of their currencies vis-à-vis the dollar, while at the same time protecting them from the volatility of world financial resources. These are Asian countries, especially China and of course Japan, which is one of the main members of this group. The other category of developing countries, which includes the Latin American countries, comprises those that do not manage to finance their needs with their exports and have to do so by resorting to indebtedness.

This system has some disturbing features, since it is based on the almost unlimited capacity of the United States to absorb all the world's imports. I always compare that country with the black holes in astronomy. The United States is receiving $10 \%$ of world saving. Nothing like this has ever been seen before. It is the great consumer, while at the same time it is financed by the other countries. It has a trade deficit of over $5 \%$ of its GDP which continues to grow in spite of the relative depreciation of the dollar vis-àvis the European currencies. Thus, it is the Europeans who are paying for all this. This is the real situation, rather than the blocs referred to in the past. The fact is that the United States has never accepted regional limits on its actions. Among the free trade agreements it has signed are treaties with Jordan, Morocco, and with African countries under its special "African Opportunity Act". The United States does not accept the idea that Africa is the backyard of the European countries, and it is disputing that situation inch by inch.

Prebisch envisaged reciprocity in real, and not merely legal, terms. This means a form of reciprocity which takes account of the differences in level of development and economic structure between countries. This gave rise to his idea of the Generalized System of Preferences, which was established at the first session of UNCTAD but which has not been adopted in the way that he expected.

Prebisch wanted the system to be multilateral, and not a unilateral system in which each country discusses and decides how it wants the preferences to be. All these ideas are now under heavy pressure in two different directions. There is a growing tendency towards the multiplication of bilateral or regional free trade agreements; these agreements almost always completely or largely ignore the differences in level of development and impose a more legalistic type of reciprocity. In addition to this phenomenon, there is another point which must be taken into account: the fact that Prebisch's thinking, or that of UNCTAD in 1964, which saw the developing countries as a compact, almost undifferentiated universe, does not correspond to the new realities of the world.

One of those new realities is the appearance on the scene of China: something that no-one could have 
imagined back in 1964, on the eve of the Cultural Revolution. Is China a developing country, or is it rather a developed country with a capacity to compete in line with very special economic rules? Generally speaking, the Asia-Pacific phenomenon stands at the other extreme from the so-called less developed countries: the 50 countries which are the poorest of the poor, the indigents of the world. In order to enter this category of the United Nations, it is necessary to be so poor that of the 35 countries of the Western Hemisphere, which of course includes Latin America, only Haiti is among those 50, out of which 34 are African, while East Timor has been the last country to join this group. Clearly, these countries are heterogeneous and they are very different from the Latin American countries, both in their history and their economic structure. Many of them have a practically subsistence-level agricultural economy. They are at a very different stage from that of the Latin American countries. What I am about to say will upset some developing countries, but this differentiation will sooner or later be reflected in the trade rules.

It is very difficult to imagine how countries like China, India, Brazil, Argentina and others can receive the same treatment as Burundi, Benin, Chad, Rwanda, Tanzania or Bhutan. Differentiation is one of the great challenges that is facing us. I could say a great deal more on this problem, but here I will limit myself to noting that this is one of the issues that were not clearly identified or dealt with in Prebisch's agenda.

I would not like to close my analysis of the changes in the world trade system without at least mentioning two fundamental matters. One is that we are witnessing a change in the very bases of the multilateral trade system. This system developed from the nineteenth century onwards on the basis of the principle of non-discrimination and the most-favourednation clause, which are expressed in the first two articles of the General Agreement on Tariffs and Trade. The proliferation of free trade agreements which exploit in a very dangerous way the terms of article 24 of the General Agreement, however, has permitted the continual erosion of that principle. In order to justify this erosion, it is claimed that free trade agreements are the elements with which to build a trade system which is totally free of hindrances. In reality, however, this is not the case, since very often those treaties create hindrances that did not exist before. To give only one example: the North American Free Trade Agreement has established rules of origin for textiles or automobile parts which did not exist before and which constitute new hindrances to the free flow of goods.

I witness this trend with great concern because, as a former Chairman of the Contracting Parties of GATT, I feel that it is my duty to defend the multilateral trade system. I also find it a matter of serious concern that, out of the whole trade of the United States, over $40 \%$ is governed by rules on preferences.

Anyone who speaks of such rules is automatically talking about rules that are discriminatory, for a very simple reason: "preference" means choosing one country or thing over another. Such differentiation is therefore automatically discriminatory. I often get the impression that what is happening today with regard to the system of trade is rather similar to what happened between 1971 and 1973, when a series of ad hoc spot decisions taken unilaterally by President Nixon practically wiped out the bases of the Bretton Woods system, at least as regards two of its cornerstones: a system of reasonably stable exchange rates, and full and free convertibility between the dollar and gold. The institutions set up as a result of Bretton Woods have survived: the International Monetary Fund (IMF) is still there, but we now have a system of fluctuating exchange rates which has nothing to do with what was agreed upon in the Articles of Agreement of the IMF in 1944. The IMF is now something else, a completely different system, and I fear that something similar is happening with the multilateral trade system. It is not that the system is going to die away, but it is being radically changed.

The second matter is the idea of interdependence, which was so important to Prebisch, who continually insisted that it was in the interest of the North - for its own benefit, of course - to promote the industrialization of the South. Prebisch always persisted with this idea: that progress - the industrialization of the Southwould create an ever-growing demand for the sophisticated products and technology of the North which would represent an additional source of demand. This is currently being proved in the case of China, to a spectacular extent. No-one could ever deny that this is the role that China is now playing, above all with respect to Japan. It is well known that one of the main causes of the recent improvement in Japan's position is its export trade with China, which is growing extraordinarily fast. The same is also true not only with respect to the United States and many Asian countries, but also Argentina and Brazil, for which China has recently been the recipient of $10 \%$ and $7 \%$ of their exports, respectively. This role that the growth of the South can play in terms of boosting world trade is not 
in the least to the detriment of the North, since it helps to increase the demand for the goods of countries like the United States.

It is interesting, for example, to observe what is happening in the case of South Korea and also Malaysia and other Asian countries. For these nations, over the last two or three years China has become their main market, surpassing that of the United States. It might even be thought that they could do without the latter country, but that is not so, for in the final analysis the United States will always be important. What does China import from South Korea? It imports different kinds of electronic components that the Chinese then use on their assembly lines, incorporate in finished products, and re-export to the United States. Thus, at the end of the line there is the great "black hole" of the United States market. Once again, we have this gigantic bloc to take into account, so that South-South trade is not an alternative, but something that exists side by side with North-South trade.

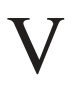

\section{By way of conclusion}

In conclusion, I should like to quote a statement by Prebisch which I always like to recall, because it forms part of the final section of his report to the first session of UNCTAD, 40 years ago. It has a great deal to do, not so much with the matters dealt with in this article, as with the underlying problems. As you will have noted, in most cases I have not offered solutions but instead have set out the problems that we will have to face.

Prebisch (1964) said in this respect: "Realism is also foresight, and an elementary sense of foresight should cause us to interpret the trend of the events that are occurring in the developing world". For this, he went on, the pages of his report were "an act of faith regarding the possibility of persuading and compenetrating with these ideas where it is necessary to penetrate and where there is a possibility of giving rise to constructive reactions".

He concluded his exhortation as follows:

"The facts are there, it cannot be denied. And if the ways of facing them suggested here are not acceptable, then we must seek other ways which are. Because the problem is inescapable. The world had never had to face it in this form or in these dimensions. Nor had the world ever had the enormous possibilities it now has to solve it, however, or the conviction - which is growing every day - that it is also possible to act in a conscious and deliberate way on the forces of technology and economics in pursuit of grand designs".

(Original: Spanish)
Bhagwati, J. (1984): Comment, in G. Meier and D. Seers (eds.), Pioneers in Development, New York, Oxford University Press.

ECLAC (Economic Commission for Latin America and the Caribbean) (2003): Preliminary Overview of the Economies of Latin America and the Caribbean, 2003, LC/G.2223-P, Santiago, Chile. United Nations publication, Sales No. E.03.II.G.186.

Prebisch, R. (1950): The Economic Development of Latin America and its Principal Problems, E/CN.12/89/Rev. 1, Santiago, Chile, Economic Commission for Latin America and the Caribbean (ECLAC).

(1964): Significance of the United Nations Conference on Trade and Development, Proceedings of the United Nations Conference on Trade and Development (Geneva, 23 March -
16 June 1964), E/CONF.46/141, New York, United Nations. United Nations publication, Sales No. 64.11.B. 12.

(1983): La crisis del capitalismo y la periferia, Problemas económicos del Tercer Mundo, Buenos Aires, Editorial de Belgrano, September.

(1984): Five stages in my thinking on development, in G. Meier and D. Seers (eds.), Pioneers in Development, New York, Oxford University Press.

Ricupero, R. (2001): La globalización de Raúl Prebisch, paper presented at the Seminar "La teoría del desarrollo en los albores del siglo XXI: Evento conmemorativo del centenario del nacimiento de don Raúl Prebisch" (Santiago, Chile, 2829 August 2001). 